\title{
転移性上顎洞癌の一例
}

\author{
世良 公志 ${ }^{1)}$ - 夜陣 紘治 ${ }^{2)}$ ・田頭 宣治 ${ }^{2)}$ 平川 |勝洋 ${ }^{2)}$

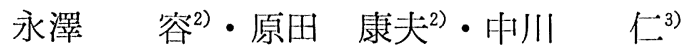

\section{A Case of Metastatic Maxillary Cancer from Sigmoid Colon Cancer}

\author{
Koji Sera \\ (Futami Chuo Hospital) \\ Koji Yajin, Nobuharu Tagashira, Katsuhiro Hirakawa, \\ Yutaka Nagasawa, Yasuo Harada and Jin Nakagawa \\ (Hiroshima University)
}

A rare case of sigmoid colon cancer that metastasized to the maxillary sinus was reported. The patient was a 74-year-old female with complaints of left cheek swelling and pain. She had undergone an operation for adenocarcinoma of sigmoid colon four years earlier. She also had metastases to the right lung and liver. A biopsy of maxillary tumor revealed that the maxillary tumor was metastatic adenocarcinoma. The patient was treated with radiotherapy, but died about 7 months later.

Key words: metastatic maxillary cancer, adenocarcinoma, sigmoid colon cancer

\section{緒言}

他臓器の悪性腫瘍が鼻，副鼻腔領域に転移す る事は極めて稀である.1872年, Perls ${ }^{1)}$ が気管 支癌の蝶形骨洞への転移を報告して以来，いく つかの文献的報告が散見されている.

しかし，これらの大部分は Grawitz 腫瘍を原 発とするもので, 消化管, 特に結腸癌を原発巣 とする報告例は極めて少ない, 最近, 我々は, 結腸癌を原発巣とする転移性上龥洞癌の一例を 経験したので若干の文献的考察を加えて報告す る.

\section{症例}

患者: 74才。 女性.
初診：昭和160年 2 月 6 日

主訴：左頓部痛. 左煩部腫脤.

家族歴：特記すべき事なし。

既往歴：昭和56年 5 月28日。広島大学第 2 外 科に扎いて, S 状結腸癌の切除術を受けた。病 理組織学的には高分化型腺癌であった.この 後, 昭和58年11月には肺及び肝転移を指摘され ている。

現病歴：昭和60年 1 月末, 左歯痛の為, 近医 歯科を受診し，粦根部膿瘍の診断にて排膿術を 受けた。 その後より左煩部痛, 左煩部腫脹が現 われ，2月 6 日当科を受診した.

現症及び検查所見: 初晾時, 左眼窩下方に硬

1）双三中央病院耳鼻咽喉科

2）広島大学医学部耳鼻咽喉科学教室

3）広島大学医学部第一病理学教室 
い皮下腫瘤が触知され，左眼窩下方より左煩部 にかけ，腫脹及び圧痛がみられた（図 1 ). 又, 鼻内所見では左中鼻道は压排による狭小化がみ られた。顔面単純及び顔面断層レ線写真では左 上顎洞上部に腫瘍状院影がみられ，左眼窩下縁 には骨欠損が疑われた（図 2，3）。

また，頭部 C Tで顔面レ線所見を裏つける， 左上顎洞前壁に一致した腫瘍陰影と前壁の骨欠 損，及び頓部皮下への浸潤像が みられた（図 4).胸部単純し線では右下葉に一致して腫瘍陰 影がみられ，横隔膜との明らかな境界はみられ ず，肺腫瘍あるいは横隔膜腫瘍と診断された が，入院後，CT，エコーにて肺転移と診断され た (図 5 )。一方, 腹部の C T検査では, 肝両葉 に low-density area が多数散在して和り, 肝腫 瘍と診断された（図 6 ）。入院時の全身所見で は, 肝が 2 横指触知され肝機能検查は GOT 70 U/I（正常 8-40）GPT $26 \mathrm{U} / \mathrm{I}$ (正常 0-40), ALP $268 \mathrm{U} / \mathrm{I}$ (正常 40-120) LAP $86 \mathrm{U} / \mathrm{I}$ (正 常 20-55）とやや上昇を示した。との他の臨床

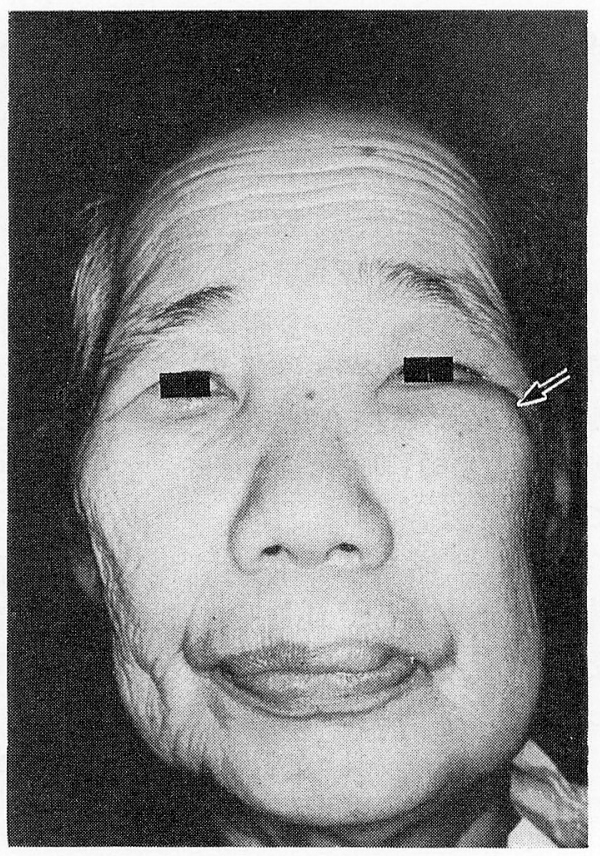

図Ｉ初䛦時左頓部腫㻛 $(\rightarrow)$.

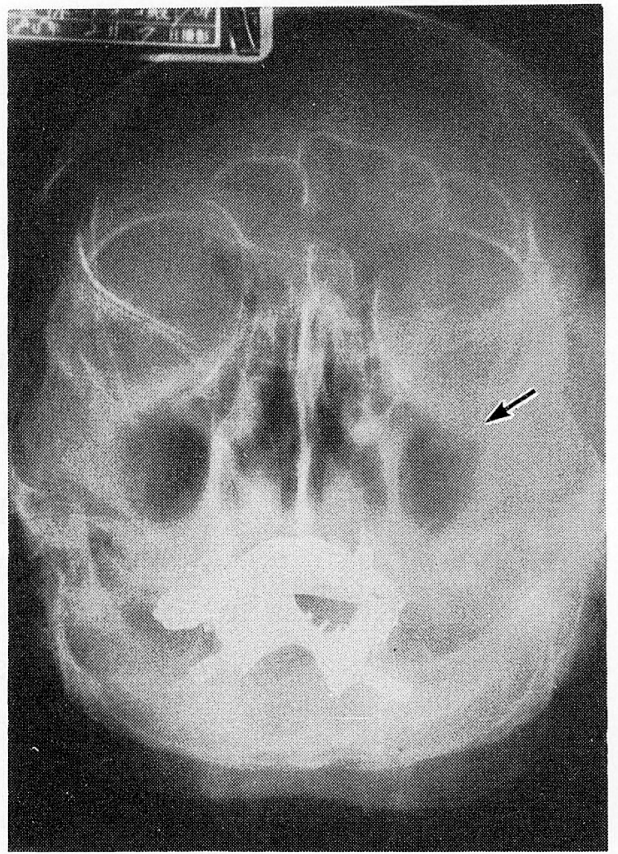

図 2 初診時 Waters 法. 矢印の如 く腫瘍状除影をみとめる。

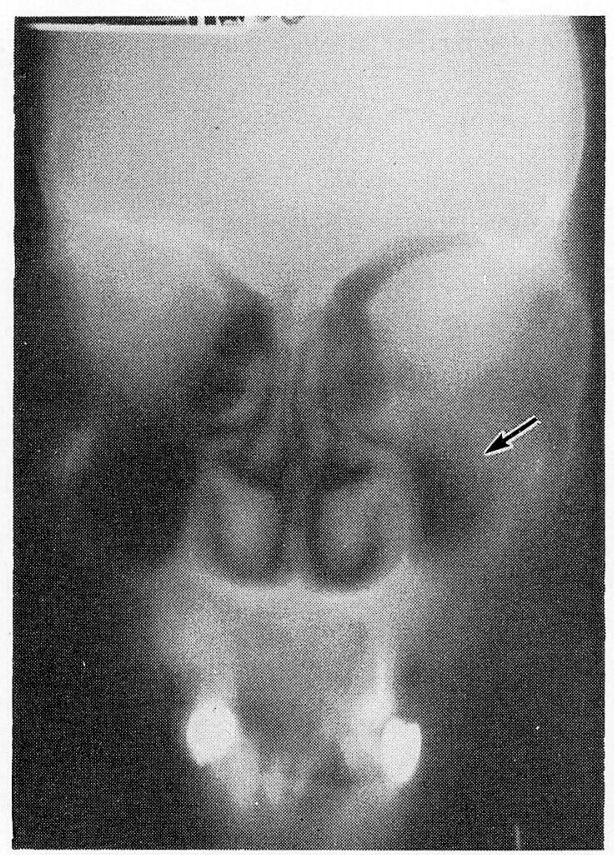

図 3 顔面断層. 矢印の如 $く$ 腫揚状 陰影をみとめる。 
生化学検查所見では特に異常を認めなかった。 な拈，昭和60年 2 月 CEA が $156.73 \mathrm{ng} / \mathrm{ml}$ と 極めて高值を示した。

入院後経過：3 月 5 日当科入院し， 3 月 6 日 左上顎試験開洞術を行ない病理学的診断の為, 組織を採取した。開洞時，左上顎洞顔面壁に は，眼窩下神経下方に骨欠損及び腫瘍がみられ た，上顎洞内では，腫場は眼窝下壁外側方より 上顎洞外側壁に存在していた（図７）。上顎洞腫 瘍の病理組織像では, 類円型の異型核及び比較 的豊かな細胞質を有した腫瘍細胞が，明瞭な腺 管を形成しつつ增殖している像がみられ，間質 には著明な線維化拈よび一部には骨組織破壊像 がみられた（図 8 )。

個々の腫痬細胞は，類门型の異型核が腺腔の 基底膜層に並び，高门柱状，弱好酸性の細胞質 をもっており，腺腔の内面には硝子像が 久ら れ, 高分化型の腺癌と診断された（図 9 ). 昭和 56年 5 月, $\mathrm{S}$ 状結腸癌手術時の病理組織像では 粘膜下層に浸潤した腫瘍がみられ，類门型の異 型核を有し，高门柱状，弱好酸性の細胞をもっ た腫瘍細胞が腺管を形成しつつ増殖して拈り, 明瞭な硝子像もみられた。これは前述の上顎洞 腫瘍の病理組織像と非常に似かよった高分化型 の腺癌の所見であった（図10).以上のような病
理学的所見から $\mathrm{S}$ 状結腸癌からの転移性上買洞 癌と㡣断された。

治療：症例は，腫瘍が眼窩下神経に一致して 存在した為と思われる左賽部痛を強く訴えた. 治療は，著明な肺転移が存在し，全身状態の悪

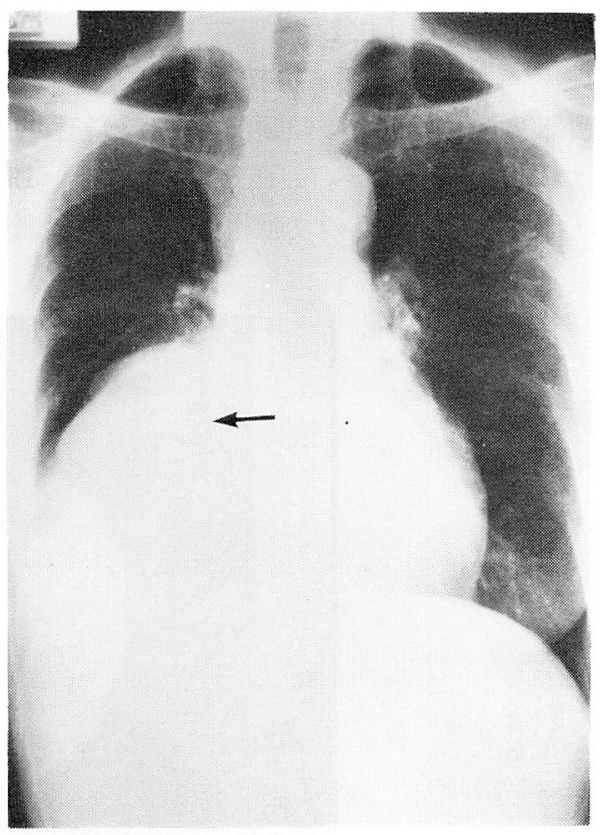

図 5 胸部正面単純レ線. 矢印の如く右 下葉に一致した腫瘍陰影がみられ る.

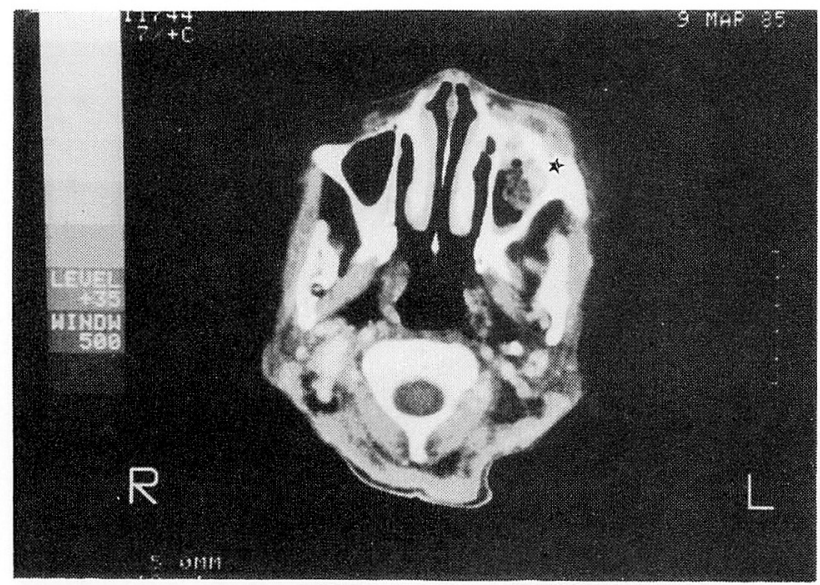

図 4 C T像. 左上顗洞前壁に一致した腫韵陰影がみられ，骨 欠損と共に煩部皮下的の浸潤がみられる（ネ）。 
化も考光られる事から，積極的な手術療法は施 行せず放射線療法を $6000 \mathrm{rad}$ 施行した。 これに よって一旦，腫陽の消失をみたが，7月頃より 再度, 上顎洞内に腫瘍の再発を認め, 煩部痛を 強く訴光た為, ガッセル神経節ブロックを施行 した. 疼痛の減少はみたものの全身状態の悪化 の為，10月13日死亡した。

\section{考按}

頸部リンパ節を除く頭頸部領域への転移性腫 瘍は少数の報告がみられるのみである。1980 年, 溝尻 $5^{2)}$ は内外の文献報告例のうち比較的
病歴の明らかな頭頸部領域への転移性腫瘍 105 例について検討を加えている。これによると原 発部位では腎癌が最も多く37例，ついで神経芽 細胞腫13例, 睪丸, 乳腺それぞれ 9 例, 消化管 8 例であり，転移部位では，鼻，副鼻腔が最も 多<34例，以下，甲状腺23例，下顎骨18例，側頭 骨11例と報告されている。また, 1965年, Fried$\mathrm{mann}^{3)}$ は71例の耳鼻咽喉科領域一の転移性腫 瘍を集計し，そのうち42例の原発巣が腎癌であ る事，さらに31例が鼻，副鼻腔への転移である 事を報告している。

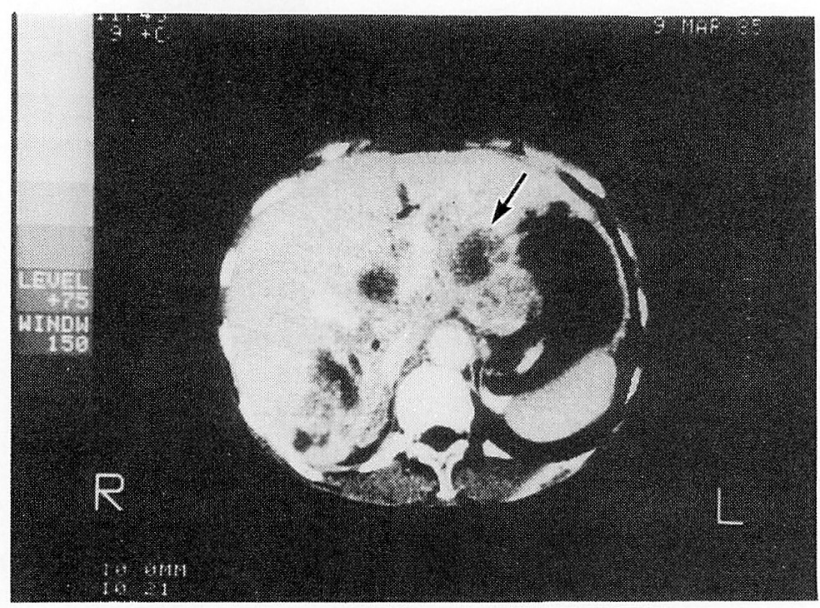

図 6 肝C T像. 肝両葉に矢印の如く low-density area が多数 散在している。

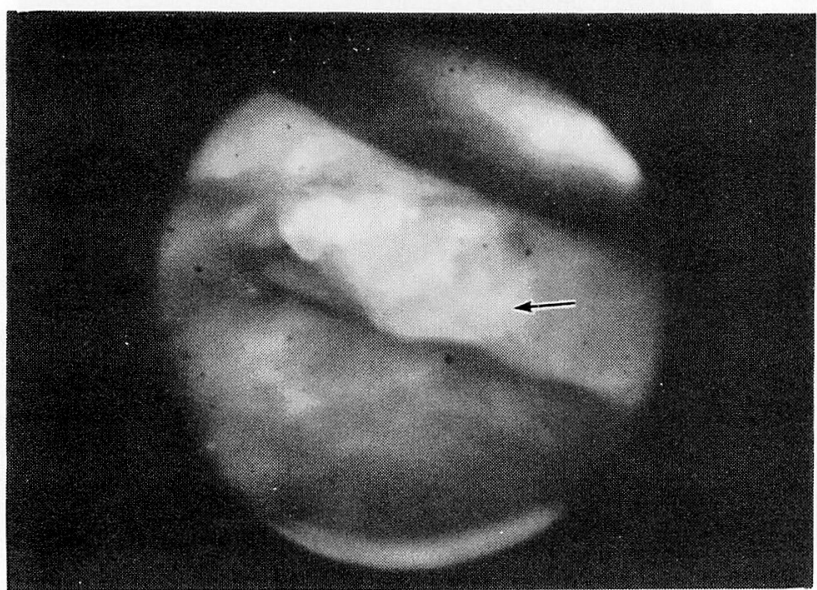

図 7 手術時所見. 上䫟洞内に矢印の如く腫瘍がみられる. 
このように頭頸部領域への転移性腫湯の原発 部位としては腎癌が圧倒的に多い，腎癌は全身 のあらゆる臓器, 組織に転移する癌として知ら れているが，耳鼻咽喉科領域への転移は現在ま で, 他の蔵器と比べて比較的少ないとされてい る。また，転移部位としては，鼻，副鼻腔が多 く，その一因としては，頭頸部領域の中では血 管組織の豊富な事があげられている。

さらに, 溝尻らは鼻, 副鼻腔への転移性腫瘍 34例について分析を行ない, 原発部位の内訳と して腎が15例，睪丸 5 例，消化管はわずか 2 例 であったと報告している。また, 1966年, Bernstein ${ }^{4)}$ は82例の鼻, 副鼻腔への転移性腫瘍のう ち約半数は腎臓よりの転移であり，ついで気管 及び肺が 10 例, 消化管よりの転移が 5 例と報告 している.このように, 鼻, 副鼻腔へ転移する 原発巣の部位としては，やはり腎蔵が多く，消

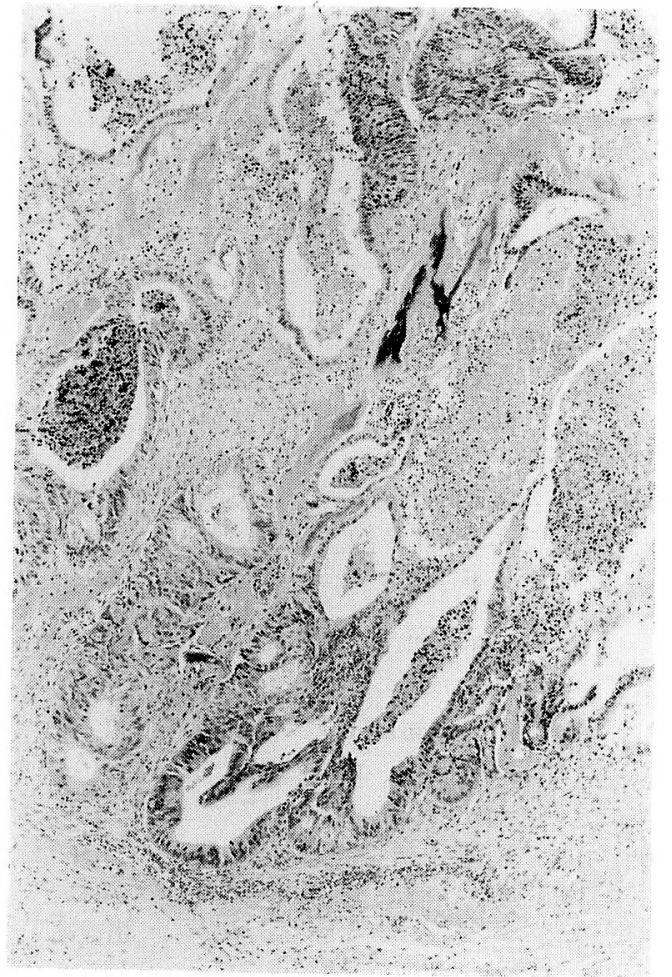

図 8 上䫟洞癌病理組織所見. 腫場細胞が明 瞭な腺管を形成しつつ增殖している。
化管は極めて稀であることがわかる.

本邦に和ける鼻, 副鼻腔への転移性腫瘍の報 告は, 我々の検索し得た限りでは表 1 の如くで あり，本例を含めると22例である。これらの原 発部位の内訳としては腎 12 例, 子宮 3 例, 大腸 2 例, 肺 1 例, 肝 1 例, 精巣 1 例, 胃 1 例, 乳 腺 1 例であり大腸癌より鼻, 副鼻腔への転移性 腫瘳の報告は，本症例が本邦において 2 例目で ある。

また，転移部位では鼻腔が11例と最も多く， 以下，篩骨洞 7 例，上䕱洞 5 例，蝶形骨洞 2 例， 前頭洞 1 例の順である。更に，転移巣による症 状が原発巣の症状に先行していたものが 22 例 中，13例にみられている事実は注目に值する。

転移巣に刘与る治療は，病歴の明らかな14例 中, 放射線単独（抗癌剂投与併用を含む）が 5 例, 手術単独 4 例, 放射線十手術併用 3 例, 抗

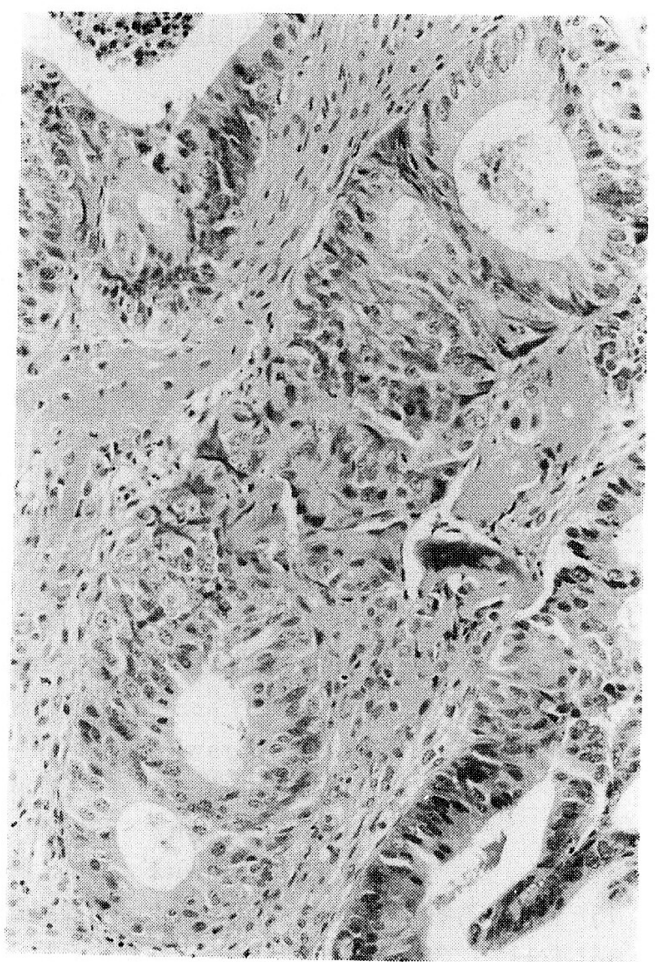

図 9 図 8 の抾大像. 腫瘍細胞では類门型の 異型核が腺腔の基底膜層に並び，腺腔 の内面には硝子像がみられる. 
癌剤単独投与 1 例, 治療不能 1 例であり, 放射 線潦法と手術療法がほぼ均等に用いられてい る.これらの症例の予後について検討してみる と, 転移巣発見以来 3 ケ月以内に死亡した症例 が 5 例又られ，また 2 年 2 ケ月以内の死亡が 8 例であった，生存例に抢ける治療方法は手術療 法 3 例, 手術療法十放射線療法 1 例, 放射線療 法 1 例, 化学療法 1 例であり, 死亡例に括ける 治療方法としては放射線療法 4 例, 手術療法十 放射線療法 2 例, 治療なし 2 例であった. 生存 例においては手術㙩法が, 死亡例に拈いては放 射線療法が多く, 本症例に招いても, 手術が可 能であれば,一般の腺癌と同様, 放射線感受性 が低いと考觉られる事から, 手術㙩法を優先さ
せた方が良い結果が得られるものと思われた。 ただし，死亡例においても 2 年 2 ケ月生存した 症例がみられる事から，原疾患を考虑した適切 な治療の必要性を考えさせられた。

本症例の如く大腸癌から鼻, 副鼻腔への転移

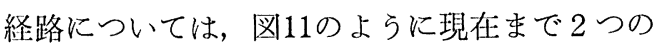
経路が考えられている577.

第一の経路としては癌細胞が大腸原発巣から 肝, 下大静脈へと流れ, 存心, 肺, 左心, 頸動 脈から息へと転移する経路である，又，第二の 経路として Nahum ら5) が主張しているように 下大静脈から椎骨静脈蔆へと向かい，頭蓋内の

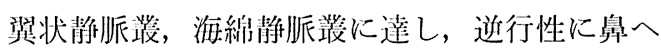
転移する経路である，現在のところ，第二の経

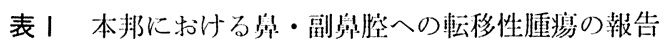

\begin{tabular}{|c|c|c|c|c|c|c|c|c|}
\hline & 報 台 & 耍者 & & 発 & 転 & $\begin{array}{c}\text { 転移笨への治療 } \\
\text { (原発紧への治) }\end{array}$ & 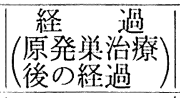 & 予後 \\
\hline 1) & 雑賀 & 㕕7) & 1982 & *大陽漓 & 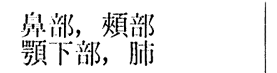 & $2 T$ 5-Fu (one) & $\begin{array}{c}2 \text { ケ月 } \\
(2 \text { 年2ケ月 })\end{array}$ & 死亡 \\
\hline 2) & 里見 & 佳眧 ${ }^{6)}$ & 1974 & ${ }^{*}$ Grawitz & 奥腔, 耳下腺 & ope (ope) & 2 年 (2年) & 生存 \\
\hline 3) & 山本 & 誠8) & 1980 & Grawitz & *奥腔，篩骨洞 & ope & $\begin{array}{c}\text { 8ケ月 } \\
\text { (3年3ケ月) }\end{array}$ & 生存 \\
\hline 4) & 小林 & 秀夫 ${ }^{9)}$ & 1951 & hepatoma & *上顎洞 & ope. RT (-) & 1 ケ月 & 死亡 \\
\hline 5) & 浅井 & 良三10) & 1960 & Gra & $\begin{array}{l}\text { *息, 上顎, 篮骨 } \\
\text { 眼, 仙関䬦 }\end{array}$ & $\begin{array}{c}\text { ope. RT } \\
(\mathrm{RT}+\text { Rイパミン) }\end{array}$ & 2 ケ月 & 生存 \\
\hline 6) & 河合純 & 郎11) & 1958 & ${ }^{*}$ Grawitz & 飾 骨 & ope (ope) & ?（4年） & 不明 \\
\hline 7) & 洴尻源 & 頁太郎2) & 1980 & 精上皮腫 & ＊篩 骨 & RT. chemo (ope) & 2 年 2 ケ月 & 死亡 \\
\hline 8) & 松崎 & 久 $^{12)}$ & 1967 & *絨毛上皮腫 & 粤中隔 & 不 明 & 不明 & 不明 \\
\hline 9) & 渡辺 & 雄司 ${ }^{13)}$ & 1981 & Grawitz & $\begin{array}{l}\text { *臭 } \\
\text { 上顎箮骨，蝶形骨洞 }\end{array}$ & $(-)$ (ope) & 不明 & 不明 \\
\hline 10) & 中島 & 成人 ${ }^{14)}$ & 1978 & Grawitz & *蝶形骨洞，骨転移 & 5-Fuのみ & 3 年 & 生存 \\
\hline 11) & 黒田 & 道弘 15 ) & 1967 & ${ }^{*}$ Grawitz & 番 腔 & $(-)$ (ope. RT) & 8日（9ケ月） & 死亡 \\
\hline 12) & 清水 & 清一16) & 1965 & Grawitz & $\begin{array}{l}\text { *叁腔, 口腔, } \\
\text { 副舜腔 }\end{array}$ & 不 明 & 2 年2ヶ月 & 死亡 \\
\hline 13) & 甲能 & 直草17) & 1978 & 肺 & *家尖部 & 不 明 & 晅後 & 死亡 \\
\hline & & & & 胃 & *節宜洞 & 不 明 & 直後 & 死亡. \\
\hline 14) & 增野 & 精二18)19) & 1980 & Grawitz & *斿顠洞 & ope. (Embolization) & 不明 & 生存 \\
\hline & & & 1979 & Grawitz & ${ }^{*}$ 上顎洞 & ope. RT (-) & 4 ケ月 & 死亡 \\
\hline & & & 1979 & Grawitz & *眼窝, 副钅腔 & ope (ope) & 7 ケ月 & 生存 \\
\hline & & & 1979 & Grawitz & *脳, 肺, 笽骨洞 & RT（不明） & 不明 & 生存 \\
\hline 15) & 宮本 & 浩明20) & 1982 & *乳 腺 & 蝶形骨洞，胃 & RT. 抗エストロダン & 1.5年(6.5年) & 生存 \\
\hline 16) & 松村 & 久 $^{21)}$ & 1948 & *絨毛上皮腫 & 具腔, 歯ぎん部 & $(-)$ & 直後 & 出血死 \\
\hline 17) & 川本 & 智22) & 1970 & *絨毛上皮腫 & 参腔，肺 & RT. chemo & 1ケ月（1年） & 死亡 \\
\hline
\end{tabular}

* : 初発症状を示した病策 


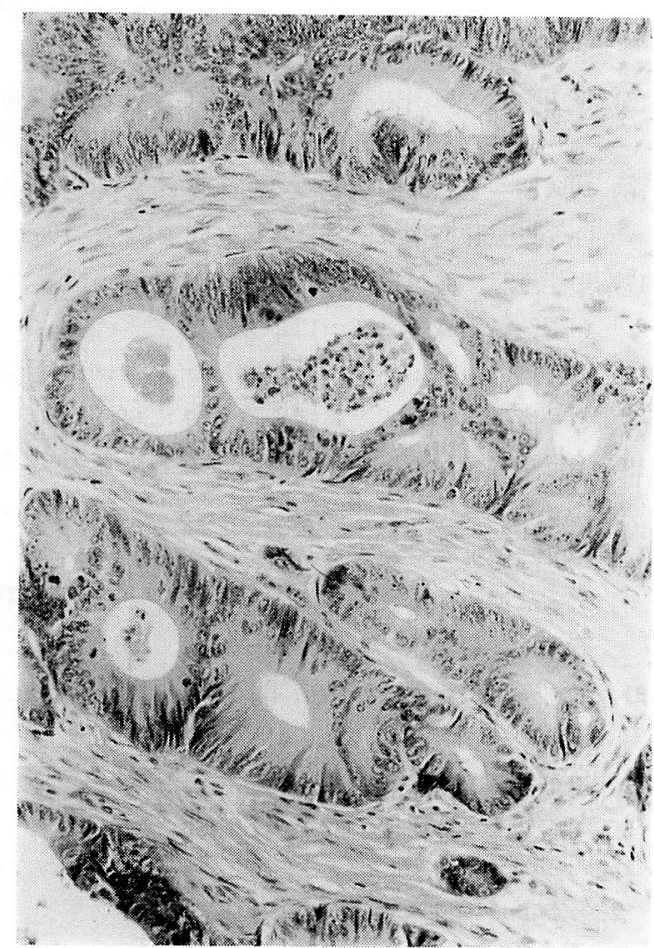

図10S 状結腸癌病理組織所見. 四 8，90 上顎洞癌の組織所見と非常に似かよっ た腫瘍細胞並びに硝子像がみられる.

\section{転移経 路}

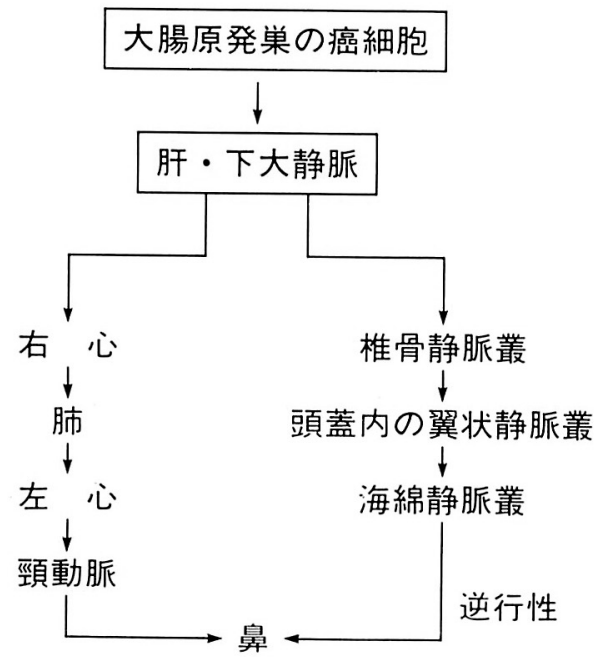

図II 転移経路
路が鼻，副鼻腔への転移経路として重要視され ているが，本症例に拈いては，肝，肺転移が早 期よりみられる事から，第一の経路がむしろ大 きく関与しているようである.

なお，里見ら ${ }^{6)}$ は 124 例の腎癌について検討 を加光, そのらち耳鼻咽唵科領域への転移は, 耳下腺 2 例, 舌 1 例, 鼻腔 1 例, 歯肉 1 例の計 5 例（ $4 \%$ ）で脳転移に匹敵する頻度であり, 耳鼻咽喉科領域への転移は，それ程稀ではない ことを示唆している。しかし，実際には耳鼻咽 喉科領域への転移の報告例は少なく，その理由 としては, 他蔵器より鼻, 副鼻腔へ転移する事 が稀であると共に, 鼻, 副鼻腔への転移性腫瘍 が症状をあらわす前に, 原発腫瘍の他藏器への 転移等の為, 死亡する事もあり, 耳鼻咽喉科領 域で充分な精査がなし得なかった例もかなり多 い為と思われる。

最後に, 一般には稀な病理組織型の腫瘍を 鼻, 副鼻腔領域に認めた場合, 転移性腫瑒も考 慮に入れ，原発巣の発見，治療に対処しなけれ ばならないと思われた。

\section{結 語}

1）74才，女性の非常に稀な $\mathrm{S}$ 状結腸癌よりの 転移性上顎洞癌症例を報告した。

2 ）現在までの本邦における他臓器よりの鼻, 副鼻腔転移報告例について文献的に考察 した.

尚, 本論文の要旨は, 日本耳息咽喉科学会第11回中 国地方部会連合請演会に於て発表した。

\section{参考文献}

1) Perls $M:$ Beiträge zur Geschwulstlehre. Virch Arch 56:437〜467, 1872.

2 ）溝尻源太郎：転移性簇'骨洞精上皮腫の 1 例. 耳喉 52 : 1053 1057, 1980.

3) Friedmann I and Osborne DA : Metastatic tumors in the car, nose and throat resion. Jour Laryngol and Otol $79: 576 \sim 591,1965$.

4) Bernstein JM : Metastatic tumors to the maxilla, nose and paranasal sinuses. The Laryngoscope $76: 621 \sim 650,1966$.

5 ) Nahum AM and Bailey BJ : Malignant tumors 
metastatic to the paranasal sinuses. The Laryngoscope $73: 942 \sim 953,1963$.

6 ）里見佳昭, 他: 腎癌の耳鼻咽喉科領域 (耳下腺, 鼻腔, 舌, 籶肉) への転移症例. 臨朱泌尿器科 $28: 43 \sim 48,1974$.

7 ）雑賀 宏, 他：帠腔転移をきたした大腸癌の一症 例. 耳鼻臨休 $75: 795 \sim 800,1982$.

8 ）山本誠, 他：重篤息出血を主訴とした腎癌

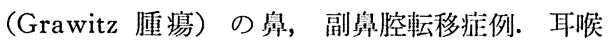
$52: 323 \sim 327,1980$.

9 ）小林秀夫：上㖽洞に転移せるへパトームの稀有な る 1 例. 日耳鼻 $54: 184 \sim 187,1951$.

10）浅井良三, 他：息腔, 副奥腔転移により発見され た Grawitz 腫瘍の 1 症例. 耳鼾臨木 53 : 939〜 947, 1965.

11）河合純一郎, 他：穊骨蜂栄に発生せる Hypernephrom の 1 例. 日耳胃 6I：315，1958.

12）松崘 久, 他: 60才女性の魚中隔部に発生した䋐 毛上皮朠の一症例. 日耳息 $70: 11: 1941,1967$.

13）渡辺雄司，他：胃副息腔に転移した腎 clear cell carcinoma の病理組織学的钼案. 副定腔 20 : $66 \sim 67,1981$.

14）中島成人，他：蝶形骨洞および多発性骨転移を来
たした腎腫瘳 (Grawitz's Tumor) 例. 耳鼻 24 : 198 204, 1978.

15）黑田道弘：鼻内転移を惹起せる Grawitz 腫瘍症: 例. 耳鼻颐床 $60: 109 \sim 112,1967$.

16）清水清一：鼻，副鼾腔及び口腔にあらわれた Grawitz 腫瘍剖検例. 日耳鼻 $68: 1522,1965$.

17）甲能直幸，他：鼻副鼾腔領域における転移癌につ いて. 奥副奥腔 16:124, 1977.

18）増野精二, 他：前頭洞に転移した Grawitz 腫瘍 の一症例について，鼻副楀腔 19:209，1980.

19）増野精二, 他：鼻副鼾腔及び頓部に転移した

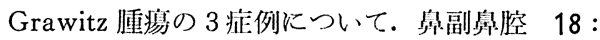
180, 1979.

20）宮本浩明，他：乳腺腫瘍の遅延型蝶形骨洞壁転移 症例. 耳鼾臨休 $75: 2559 \sim 2565,1982$.

21）松村 久：鼻部及び歯歒部に転移した悪性䋐毛上 皮腫の一例. 耳舅臨床 $41: 9 \sim 12,1948$.

22）川本 智, 他：帠腔転移をきたした絨毛上皮腫の 1 症例. 耳是臨床 $63: 481 \sim 488,1970$.

$$
\left(\begin{array}{l}
\text { 別刷倩求先 : 世良公志 } \\
\text { 干728 } \text { 三次市十日市町650 } \\
\text { 双三中央病院耳鼻咽喉科 }
\end{array}\right)
$$

